\title{
ファモチジンの蓄積による沉血球減少症が 疑われた透析症例
}

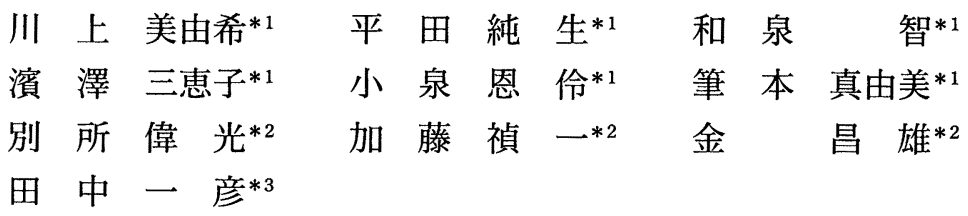

【緒言】

ヒスタミン $\mathrm{H}_{2}$ 受容体遮断薬famotidineは低湿度で 強力かつ持続的な胃酸分泌抑制作用を持ち，臨床 的に広く使用されている。透析患者では上部消化 管に起きるびらん，潰㾝の頻度が高いといわれて おり，上部消化管出血なども併発しやすいため， $\mathrm{H}_{2}$ 受容体遮断薬が頻繁に用いられる. Famotidineは 腎排泄型薬物であるため，腎機能の低下に伴い消 失半隇期が延長する，以前より腎不全患者におい て, famotidineの蓄積が原因と考えられる錯乱，痤 繁，昏睡などの精神神経障害が問題にあげられて いたが，最近，腎不全患者に起こりやすい famotidineの副作用として, 血液障害も厚生省副作 用報告において取り上げられている．今回，当院 においいても famotidine $20 \mathrm{mg}$ /日を投与していた透析 患者において, 汎血球減少症を経験したので報告 する。

【症例および経過】

症例） 80 才，男性. 透析歴 3 年 3 力月. 平成 9 年 9 月 9 日，通院時に転倒し，腰椎圧迫骨折のため入院.

身体所見）身長 $154 \mathrm{~cm}$ ，体重 $48.8 \mathrm{~kg}$ 入院時検查所見) WBC $5900 / \mu \mathrm{l}, \mathrm{RBC} 313 \times 10^{4} / \mu \mathrm{l}$, $\mathrm{Hb} 9.4 \mathrm{~g} / \mathrm{dl}$, Ht $29.3 \%$, PLT $13.8 \times 10^{4} / \mu \mathrm{l}$ 発症時処方) famotidine $20 \mathrm{mg}$ 寝前, alfacalcidol $0.25 \mu \mathrm{g}$ 朝食後, sennoside pod $1 \mathrm{~g}$ 寝前, $\mathrm{CaCO}_{3} 2 \mathrm{~g}$ 昼夕食後, sennoside $12 \mathrm{mg}$ 寝前, loxoprofen sodium $120 \mathrm{mg}$ 朝夕食後, cisapride $7.5 \mathrm{mg}$ 毎食後,

*1 特定医療法人仁真会白䉆病院薬剤科

于 546-0002 大阪市東住吉区杭全 7-11-23

*2 特定医療法人仁真会白䣨病院診療部

*3 大阪薬科大学臨床薬剤学 potassium gluconate $10 \mathrm{mEq}$ (Kとして) 朝夕食後 経過）ベット上安静にて治療していたが，11月中 旬より WBC $3430 / \mu \mathrm{l}$, PLT $5.4 \times 10^{4} / \mu \mathrm{l}$ と低下, PT 16.6秒, 出血時間 10 分 30 秒と延長し, 出血頓向が 認められた. FDP $2.5 \mu \mathrm{g} / \mathrm{ml}$ と正常範囲内のため, DICは否定され，薬剤性の副作用が疑われた。投薬 内容中で白血球減少症，血小板減少症の報告のあ るものは, famotidine, loxoprofen sodium, cisapride であった。この3凨のうち，腎不全症例の占める割 合が多く見られたことよりfamotidineを最も疑い， 投与を中止して血漿搌度測定を行った. Famotidine 投与中止後 9.5 時間の浱度は $226 \mathrm{ng} / \mathrm{ml}$ ，投与中止後 38時間の透析直前湦度は $147 \mathrm{ng} / \mathrm{ml}$, 投与中止後 42 時間の透析直後浱度は $105 \mathrm{ng} / \mathrm{ml}$ であり, famotidine の胃酸分泌 $50 \%$ 抑制瀑度 $13 \mathrm{ng} / \mathrm{ml}$ に比べ著しく高 值であった。非透析時の 2 点より $\mathrm{t}_{1 / 2}$ を求めると 45.8 hrであり，腎機能正常者の $2.5 \mathrm{hr}$ に比べ約 18 倍にも 延長していた．透析時の $\mathrm{t}_{1 / 2}$ は $4.8 \mathrm{hr}$ ，透析による血 槳浱度低下率は28.7\%であった(Fig.1)，また，血 球検査值の変動を追跡したところ, famotidineを中 止する以前は，PLT，WBCともに減少頋向にあっ

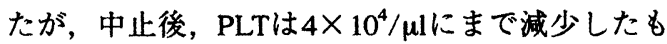
のの, 両者とも徐々に回復が認められた (Fig.2).

\section{【考察および結語】}

Famotidineの胃酸分泌抑制作用は強力で，胃酸分 泌 $50 \%$ 抑制浱度は $13 \mathrm{ng} / \mathrm{ml}$, 胃酸分泌 $75 \%$ 抑制浱 度は $50 \mathrm{ng} / \mathrm{ml}$ といわれている。 今回我々は， famotidine $20 \mathrm{mg}$ /日投与により血漿浱度が $226 \mathrm{ng} / \mathrm{ml}$ を示し，沉血球減少症が疑われた症例を経験した。

Famotidneが沉血球減少症を引き起こすメカニス ムは明らかにされてはいないが，中毒性または免 


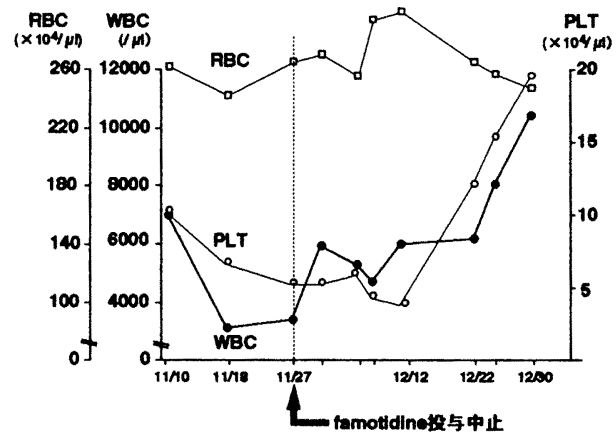

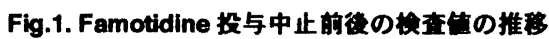

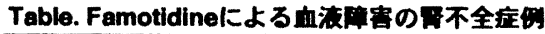
慧者投与方法 白血球血小板発现日数枟禹

\begin{tabular}{|c|c|c|c|c|c|}
\hline 1.76才男性 & 40mg 舴注 & $\downarrow$ & $\downarrow$ & 8 & 霍快 \\
\hline 2.76才女性 & $10 \mathrm{mg}$ * & $\downarrow$ & $\downarrow$ & 6 & 死亡 \\
\hline \multirow[t]{2}{*}{ 3.68才女性 } & 40mg 経口 & & & & \\
\hline & 40mg 般注 & $\downarrow$ & $\downarrow$ & 8 & 死亡 \\
\hline
\end{tabular}

疫反応により起きることが考えられている.中毒 説として, Byron $ら^{1)}$ は $\mathrm{H}_{2}$ 受容体 agonistである 4-methyl histamineが細胞周期の静止期にある造血 幹細胞をDNA 合成期に移行させる作用があり，in vitroでは cimetidineが骨鲔の $\mathrm{H}_{2}$ 受容体の阻害剤とし て強い効果があるとことを確認した。さらに cimetidineはマウスのCFU-SのDNA合成を阻害する ことによって骨髄造血幹細胞の分化, 成熟を阻害 する可能性を報告した。 Fitchenら ${ }^{2)}$ は高濃度の cimetidineがCFU.Cを減少させることを, Amos ら ${ }^{3)}$

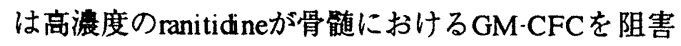
することを認めている，また，免疫反応説として， Roklinら ${ }^{4)}$ はサプレッサーT細胞にヒスタミン $\mathrm{H}_{2}$ 受 容体が存在し, cimetidineによりヒスタミン $\mathrm{H}_{2}$ 受容 体に対するヒスタミンの結合が阻害され，PHAに よるリンパ球幼弱化試験が元進することを報告し ている、Marら ${ }^{5)}$ は白血球減少症および血小板減少 症を起こした症例の血清中に白血球凝集素を認め, cimetidine-免疫複合体が白血球，血小板を破壊する 可能性を述べている.

1997年3月までの承認時および市販後調查におい て, famotidineによる血液障害の副作用報告例のう ち, 焣不全合併例は6例あり，その詳細を確認でき た3症例をTableに示す.このうち 1,3 症例では, 常用量が投与されていた。また，famotidineの経口 投与での腸管吸収率は不完全で約37\%と低いため, 経静脈内投与する際には経口投与量のおよそ半量

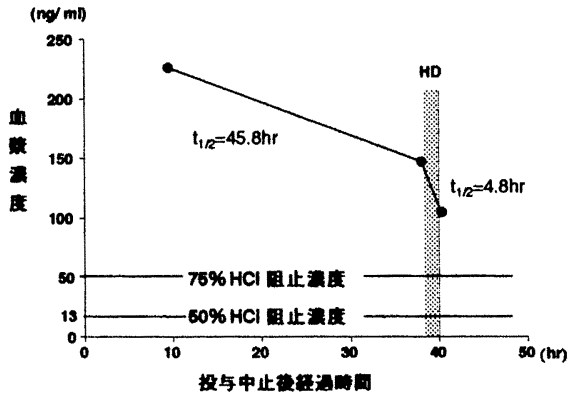

Fig.2. Famotidine 血悲湿度の推移

以下が至適量とされている．従って，1，3の症例 ではfamotidineがかなりの高浱度の状態にあったこ とが推测される。

我々が経験した本症例での骨能毒性は，患者が 透析を施行している末期腎不全患者で, famotidine が蓄積しやすい状態であったことや測定した famotidine浱度は透析で低下しているにもかかわら ず高值であったことから，famotidineの蓄積による 中毒性の反応により起きたことが推測された。

透析患者における famotidineの投与では, famotidineの蓄積による中毒性反応が起こる可能性 があり，投与量および副作用の簃重な管理が必要 である。

【引用文献】

1) Byron, J. W. : Cimetidine and bone marrow toxity. Lancet, 10 : 555-556 (1977).

2) Fitchen, J. H. and Koeffler, H. P. : Cimetidine and granulopoiesis : Bone marrow culture studies in normal man and patients with cimetidine-aociated neutropenia. Brit. J. Haemat., 46 : 361-366 (1980).

3) Amos, R. J., Kirk, B., Amess, J. A. L. et al. :Bone marrow hypoplasia during intensive care : Bone marrow culture studies implicating ranitidine in the suppression of haemopoiesis. Human Toxicol., 6 : 503-506 (1987).

4) Rocklin, R. E., Breard, S., Gupta, S. et al. :Characterization of the human blood lymphocytes that produce a histamine-induced suppressor factor (HSF) . Cellular Immunology, 51 : 236-237 (1980).

5) Mar, D. D., Brandstetter, R. D., Miskovitz, P. F. et al. : Cimetidine-induced, immune-mediated leukopenia and thrombocytopenia. South Med. J., 75 : 1283-1285 (1982). 